\title{
Effect of Irrigation on the Changes in Wetland Rice Productivity (Oryza Sativa L.) due to a Climate Change in North Sumatra Province
}

\section{Hasbul Hadi and Diana Chalil}

Agribusiness Study Program, Faculty of Agriculture, Universitas Sumatera Utara, Indonesia

\begin{abstract}
Climate change is one of serious threats to the agricultural sector. In North Sumatra Province, climate change is characterized by shorter rainy season with higher rainfall. To overcome such climate change, it is necessary to provide irrigation that can accommodate excessive rain water and distribute it in times of shortage. Therefore, changes in rainfall will not be too influential on productivity. This is especially important for plants that need a lot of water like rice. To analyze the influence of irrigation in North Sumatra Province, the data were collected from 27 regencies/cities in 2011 - 2015 and were analyzed using a Simple Linear Regression analysis model. The estimation results show that irrigation can push the productivity variances. The irrigation regression coefficient of 0.133432 shows that each increase of irrigation area by $1 \%$ will decrease the productivity variation by 0.13 tons/ha.
\end{abstract}

Keywords: irrigation, productivity, rainfall, wetland rice

Received 02 March 2018 | Revised 23 March 2018 | Accepted 26 March 2018

\section{Introduction}

Climate has an important role in supporting the growth and production of crops. Climate components include temperature, humidity and rainfall. Climate cycles may experience changes that have negative impacts such as a shortened rainy season but with high rainfall. Such uneven distribution of rainfall can result in crop losses or declining crop yields. To overcome such unfortunate situation, one of the possible solutions is through irrigation that can save a large amount of rainfall and distribute it evenly. Efficient water management can increase crop intensity, reduce water discharge requirements and reduce drought impact [1]. Irrigation can improve tillage and cultivation [2]. One of the examples of utilizing irrigation in overcoming the climate change problem can be seen in Pakistan. The results of the research done by Mirza et al. [3] show that climate change has only resulted in relatively small negative effects on the food crop sector in Pakistan due to the availability of irrigation and tube wells.

*Corresponding author at: Agribusiness Study Program, Faculty of Agriculture, Universitas Sumatera Utara, Jl. Prof. Sofyan No. 3, Medan 20155, Indonesia

E-mail address: hasbulhadi1@gmail.com 
North Sumatra is one of the centers for rice production in Indonesia prepared to become one of the provinces that will support food self-sufficiency in Indonesia. Availability, effectiveness and efficiency of adequate irrigation are needed. Irrigations are available in almost all regencies/cities in North Sumatra Province, nevertheless, the width of irrigation area in each of the regencies/cities varies as shown in Table 1 below.

Table 1. The Development of Irrigated Area in North Sumatra Province in $2011-2015$

\begin{tabular}{|c|c|c|c|c|c|}
\hline \multirow{2}{*}{ Regency/City } & \multicolumn{5}{|c|}{ Irrigated Area (Ha) } \\
\hline & 2011 & 2012 & 2013 & 2014 & 2015 \\
\hline Nias & 1,434 & 7,544 & 857 & 1,415 & 1,240 \\
\hline Mandailing Natal & 16,785 & 7,095 & 18,042 & 17,604 & 19,493 \\
\hline Tapanuli Tengah & 16,093 & 10,149 & 15,777 & 16,323 & 15,686 \\
\hline Tapanuli Selatan & 10,878 & 6,724 & 10,611 & 10,254 & 8,658 \\
\hline Tapanuli Utara & 16,879 & 5,661 & 17,022 & 17,022 & 17,628 \\
\hline Toba Samosir & 18,269 & 11,843 & 18,416 & 18,215 & 18,554 \\
\hline Labuhan Batu & 591 & 580 & 591 & 591 & 591 \\
\hline Asahan & 5,671 & 8,086 & 6,567 & 6,650 & 6,650 \\
\hline Simalungun & 42,247 & 27,189 & 41,422 & 43,689 & 35,060 \\
\hline Dairi & 10,125 & 3,965 & 10,114 & 10,115 & 9,977 \\
\hline Karo & 10,667 & 7,526 & 9,618 & 11,188 & 11,228 \\
\hline Deli Serdang & 26,069 & 17,286 & 23,653 & 24,276 & 23,452 \\
\hline Langkat & 7,091 & 8,861 & 8,379 & 8,384 & 8,863 \\
\hline Nias Selatan & 3,803 & 4,360 & 2,797 & 1,332 & 2,249 \\
\hline $\begin{array}{l}\text { Humbang } \\
\text { Hasundutan }\end{array}$ & 11,635 & 10,000 & 11,199 & 11,199 & 11,268 \\
\hline Pakpak Bharat & 1,410 & 781 & 1,393 & 1,495 & 1,340 \\
\hline Samosir & 3,394 & 1,581 & 3,411 & 3,475 & 3,578 \\
\hline Serdang Bedagai & 34,148 & 30,208 & 32,413 & 33,556 & 33,094 \\
\hline Batubara & 16,309 & 9,761 & 14,399 & 15,279 & 14,999 \\
\hline $\begin{array}{l}\text { Padang Lawas } \\
\text { Utara }\end{array}$ & 11,625 & 2,549 & 8,029 & 9,755 & 9,755 \\
\hline Padang Lawas & 12,325 & 5,090 & 6,630 & 6,758 & 6,311 \\
\hline $\begin{array}{l}\text { Labuhan Batu } \\
\text { Selatan }\end{array}$ & 359 & 223 & 429 & 422 & 460 \\
\hline $\begin{array}{l}\text { Labuhan Batu } \\
\text { Utara }\end{array}$ & 1,278 & 1,190 & 800 & 800 & 800 \\
\hline Nias Utara & 1,422 & 5,904 & 1,422 & 2,706 & 1,943 \\
\hline Nias Barat & 168 & 773 & 118 & 64 & 0 \\
\hline Tanjung Balai & 140 & 165 & 110 & 164 & 164 \\
\hline Pematang Siantar & 2,209 & 2,141 & 2,078 & 2,316 & 2,226 \\
\hline Tebing Tinggi & 465 & 380 & 390 & 315 & 315 \\
\hline Medan & 468 & 136 & 468 & 553 & 529 \\
\hline Binjai & 657 & 1,214 & 657 & 657 & 657 \\
\hline Padang Sidempuan & 3,649 & 2,778 & 3,809 & 2,861 & 3,001 \\
\hline Gunungsitoli & 1,399 & 507 & 1,431 & 527 & 1,133 \\
\hline
\end{tabular}

Source: Central Bureau of Statistics of North Sumatra Province (2011 - 2015), processed in (2017)

The differences in the area of irrigated land probably due to the differences in rainfall distribution characteristics, infrastructure conditions, irrigation networks and cultivation techniques [1]. The data in Table 1 show that Deli Serdang, Serdang Bedagai and Simalungun Regencies, which are rice production centers in North Sumatra Province are the areas that 
possess the most extensive irrigated land, but at the same time also have a tendency to decrease which can affect the stability of rice production in North Sumatra Province. Using quarterly data from 5 production centers in North Sumatera, the results of the research done by Hadi et al. [4] show that rainfall is one of the climate change components in addition to temperature and humidity which significantly affects rice production in North Sumatra Province. However, the temperature and humidity in North Sumatra Province are still within the optimal range for rice cultivation, i.e. $24^{\circ} \mathrm{C}-30^{\circ} \mathrm{C}$ and $80 \%-88 \%$. However, the average monthly rainfall in North Sumatra Province is $67-455 \mathrm{~mm} /$ month which is relatively fluctuating and is outside the optimal range of $200-250 \mathrm{~mm} / \mathrm{month}$. As described in the research done by Hosang et al. [5], one of the decreasing rice productivity caused by climate change is the quite high increase of rainfall. Thus, through a good irrigation system, rice productivity cannot be disturbed even when the climate changes, and the government's planned food self-sufficiency program will not be disturbed. This research was conducted to determine the effect of irrigation on changes in productivity of wetland rice (Oryza sativa L.) due to climate changes in North Sumatra Province.

\section{2. he hod}

\subsection{Research Location}

The research was conducted in North Sumatra Province which is one of rice production centers in Indonesia. All regencies/cities in the Province of North Sumatra, except Sibolga Regency, were used as the sample of the locations so that the diversity of irrigated land would be obtained.

\subsection{Data Collection Method}

The data were secondary data obtained from the irrigated land area and the productivity of wetland rice in 32 regencies/cities. Due to limited availability of data, the data collected were annual data from 2011 to 2015 from the Agriculture Office of North Sumatra Province and the Central Bureau of Statistics of North Sumatra Province. The total number of data was 160.

The effect of irrigation on changes in wetland rice productivity was analyzed using a simple linear regression model with the equation of

$$
\mathrm{V}=\mathrm{f}(\mathrm{x}, \beta, \varepsilon)
$$

here $V=$ Productivity Variance (ton/ha), $x=$ Percentage of Irrigated Area (\%), $\beta=$ Regression Coefficient and $\varepsilon=$ error term. The variance was calculated using the formula:

$$
\text { variance }=\frac{\sum_{\bar{i}=1}^{n}\left(Y_{\bar{i}}-\bar{Y}\right)^{2}}{n} \text { ton/ha }
$$


where $\mathrm{Yi}$ and $\mathrm{Y}$ are the production of the i-data and the average of production and $\mathrm{n}$ is the number of observations.

The effect of climate change was analyzed by productivity variance due to changes in the percentage of irrigated area. Prior to the estimation, the data were condensed by discarding the outliers and then classical assumption tests were conducted including normality test using Kolmogrov Smirnov test, linearity test using Ramsey RESET test, heterocedastisity test using Scatter Plot, multicollinearity test by looking at VIF and Tolerance values and autocorrelation test using Drubin-Watson test.

\section{Results and Discussion}

From the calculation of the percentage of irrigated land and productivity variance for each regency/city in North Sumatra Province, the following results were obtained.

Table 2. Percentage of Irrigated Land and Productivity Variance

\begin{tabular}{lcc}
\hline \multicolumn{1}{c}{ Regency/City } & Productivity Variance & Percentage of Irrigated Land \\
\hline Nias & 8.58 & 30.61 \\
Mandailin Natal & 8.08 & 41.29 \\
Tapanuli Tengah & 0.51 & 46.39 \\
Tapanuli Selatan & 4.97 & 32.08 \\
Tapanuli Utara & 12.13 & 57.50 \\
Labuhanbatu & 24.53 & 2.35 \\
Simalungun & 1.38 & 40.59 \\
Dairi & 15.79 & 45.40 \\
Karo & 4.60 & 42.07 \\
Deli Serdang & 2.58 & 29.03 \\
Langkat & 4.23 & 10.99 \\
Nias Selatan & 20.85 & 14.07 \\
Humbang Hasundutan & 0.61 & 58.03 \\
Pakpak Barat & 4.07 & 22.70 \\
Samosir & 3.36 & 35.87 \\
Serdang Bedagai & 1.13 & 47.70 \\
Batubara & 6.70 & 40.41 \\
Padang Lawas Utara & 2.04 & 43.11 \\
Padang Lawas & 2.01 & 47.37 \\
Labuhan Batu Selatan & 10.17 & 51.66 \\
Labuhan Batu Utara & 3.42 & 3.48 \\
Nias Barat & 15.76 & 8.15 \\
Pematang Siantar & 4.82 & 58.75 \\
Tebing Tinggi & 7.26 & 46.52 \\
Medan & 6.79 & 12.86 \\
Binjai & 0.80 & 21.84 \\
Padang Sidempuan & 0.95 & 31.80 \\
\hline Source: Processed & &
\end{tabular}

Source: Processed data (2017)

The data presented in Table 2 show that the range of productivity variance is quite high. The percentage of irrigated area in North Sumatra Province is $2.35 \%$ to $58.75 \%$. Some 
regencies/cities are found to have their variance value below 1 ton/ha such as Tapanuli Tengah, Humbang Hasudutan, Binjai and Padang Sidempuan. However, some other regencies/cities are found to have their variance value above 20 tons/ha such as Labuhan Batu and Nias Selatan. Labuhan Batu Regency has a high productivity variance value (24.53) with a very low percentage of irrigated area $(2.35 \%)$. In contrast, the lowest productivity variance value is found in Tapanuli Tengah Regency (0.51) which is one of the production centers in North Sumatra Province that has a high percentage of irrigated area (46.39\%). However, there is also a regency with a high percentage of irrigated area $(45.50 \%)$ and with a high productivity variance value (15.79), such as Dairi Regency.

The area with a percentage range close to $58.75 \%$ is the area that has a relatively high level of productivity, i.e. the center for wetland rice production in North Sumatra Province. The average productivity in the center areas is 51.38 tons/ha with the productivity variance ranging from 0.40 tons/ha to 6.46 tons/ha. Meanwhile, in the non-center for wetland rice production, the average productivity is 37.03 tons/ha with the productivity variance ranging from 0.48 tons/ha to 20.85 tons/ha. The percentage of irrigation $(2.35 \%)$ in the non-center areas is expected to push wetland rice productivity by maintaining or optimizing benefits from the existing irrigation. Although the productivity of non-center areas is relatively low, the additional productivity can reach $97.65 \%$ if the existing irrigation can be maintained at its maximum potential level.

The results of normality test showed that the Kolmogrov Smirnov value was 0.27 on the significance of $5 \%$. For the linearity test using Ramsey RESET, the value obtained was 0.29 showing that the linear specification could not be rejected on the significance of $5 \%$. In addition, based on the Durbin Watson autocorrelation test, the result obtained (2.11) indicated that the data did not encounter autocorrelation problems. Furthermore, from the multicollinearity test, the VIF value of $1<10$ and the Tolerance value of $1>0.1$ indicated that the model was also free from multicollinearity problem. Moreover, the heterocedasticity test using the Scatterplot chart showed that there was no clear pattern, meaning that the model was homocedastic. Therefore, a simple linear regression estimation can be continued with the result presented in Table 3 below.

Table 3 shows that the area of irrigated land has a significant effect on changes in wetland rice productivity in North Sumatra Province. The availability of irrigation can push productivity variances. The results of the research done by Hadi et al. [4] found a regression coefficient of rainfall at 51,772 indicating that any increase of rainfall of $1 \mathrm{~mm}$ per quarter would increase rice production in North Sumatra Province by 51,772 tons per quarter. The irrigation regression coefficient in Table $3(-0.133)$ indicates that each increase of irrigation area by $1 \%$ will decrease the productivity variance by $0.13 \%$ tons/ha. Improvements that can be generated in the presence of irrigation are not too large because, as described earlier, the climate change in North Sumatra 
Province is not so extreme. In addition, changes in productivity are also significantly influenced by such other factors as temperature, humidity and fertilizing [4]. Thus, the value of $\mathrm{R}^{2}$ is also quite low at $12.75 \%$. However, this result needs further study using monthly or quarterly data since the average harvest age of wetland rice is generally 100 days [6].

Table 3. Estimation Results

\begin{tabular}{lcccc}
\hline \multicolumn{1}{c}{ Variable } & Coefficient & Standard Error & t-Statistic & Prob. \\
\hline Constants & 11.156 & 2.652 & 4.207 & 0.00 \\
Irrigation & -0.133 & 0.070 & -1.912 & 0.06 \\
\hline R-squared & & 0.13 & & \\
Durbin-Watson stat & & 2.12 & & \\
F-statistic & & 3.65 & \\
Prob(F-statistic) & & 0.06 & \\
\hline
\end{tabular}

Note: $\alpha_{0.1}=10 \%$

Source: Processed data (2017)

Subsequent research also needs to consider the irrigation conditions in each regency/city. In this research, the irrigation variation is only seen from the quantity, not the quality; whereas the quality of irrigation networks has an important role. The result of the research done by Ruminta [7] found that the decrease of wetland rice production was due to the absence of adequate irrigation, so that the land has the potential to encounter drought and flood. Consequently, optimizing irrigation networks should receive attention by rehabilitating damaged irrigation networks. Rehabilitation by increasing irrigation networks supported by the farmers' awareness of the importance of irrigation networks for the sustainability of rice production in North Sumatra Province is urgently needed [8].

\section{Conclusions}

The availability of irrigation can stabilize the impacts of a climate change occurring in North Sumatra Province. The regression coefficient value of -0.133 indicates that the increase of irrigated land by $1 \%$ can reduce the variance of wetland rice productivity by 0.13 tons/ha.

\section{REFERENCES}

[1] Balai Besar Penelitian Tanaman Padi, Teknik irigasi hemat air. Jawa Barat: Kementrian Pertanian, 2015.

[2] H. S. Hasibuan, "Analisa kebutuhan air irigasi daerah irigasi sawah Kabupaten Kampar," Journal Aptek, vol. 3, no. 1, pp. 97-102, 2010.

[3] A. N. Mirza and M. Schmitz, "Economic assessment of the impact of climate change on agriculture of Pakistan," Bussines and Econmic Horizons, vol. 4, no. 1, pp. 1-12, 2011.

[4] H. Hadi, D. Chalil, and Rahmanta, "Pengaruh perubahan iklim terhadap produksi padi sawah di Provinsi Sumatera Utara," Skripsi, Fakultas Pertanian, Universitas Sumatera Utara. Medan, 2017. 
[5] P. R. Hosang, J. Tatuh, and E. X. Johannes," Analisis dampak perubahan iklim terhadap produksi beras Provinsi Sulawesi Utara Tahun 2013-2030," Eugenia, vol. 18, no. 3, 2012.

[6] Balai Besar Penelitian Tanaman Padi, Klasifikasi umur padi. Jawa Barat: Kementrian Pertanian, 2015.

[7] Ruminta, "Analisis Penurunan Produksi Tanaman Padi Akibat Perubahan Iklim di Kabupaten Bandung Jawa Barat," Journal Cultivation, vol. 15, no. 1, 2016.

[8] N. I. Minsyah, A. Meilin, and Endrizal, Optimalisasi pemanfaatan lahan sawah irigasi untuk peningkatan produksi padi sawah di Provinsi Jambi. Jambi, 2015. 